\title{
UDC 372.881.111.1
}

Tetiana Kravchyna

$\mathrm{Ph} . \mathrm{D}$ in Pschylogy, Associate Professor, Foreign Languages Department

Khmelnytsky National University

tkravchyna@gmail.com

ORCID: 0000-0001-8407-6667

\section{DISTANCE LEARNING IN TEACHING ENGLISH: ADVANTAGES AND DISADVANTAGES}

\begin{abstract}
Foreign languages e-learning has gained in a great importance because of growing interest in the Internet. It becomes a very popular method due to its accessibility, simplicity and availability, which contribute to improvement of spectrum and quality of distance learning in teaching English in higher educational establishments in pandemic conditions. Mechanism of education is a key process of human life, which determines the personality development. Fast pace of information technology development brings on displacement of traditional learning in higher education establishments with more modern methods including distance learning in teaching English. This article attempts to reflect the current trends in foreign language learning using distance technology. Currently, new technologies and the Internet allow the person to gain the necessary knowledge without leaving home, using a personal computer. This article considers the advantages and disadvantages of distance learning in teaching a foreign language compared to fulltime and part-time education. The survey has confirmed that quality and structure of educational courses are usually much better with distance learning than with traditional training forms. Distance learning comprises all actual learning methods and suggests a large number of assignments designed for independent study, with the probability of obtaining day-to-day consultations. It uses the latest accomplishments of interactive and information technologies and gives equal educational opportunities to students regardless of health, place of residence, financial security and elitism. Besides, the disadvantages of this form of learning over other forms and the reasons why distance education may be ineffective are given and explained in the article (lack of face-to-face conversations, one-side explanation and lack of constructive skills). The student must also have certain psychological traits and technical means such as a computer and an access to the Internet. The conclusions made as a result of the comparison allow to determine the areas that need special attention, as well as to choose the most convenient tools for effective learning of foreign languages and English, in particular.
\end{abstract}

Keywords: teaching; distance learning; English; advantages and disadvantages; modern technologies

Introduction. The introduction of quarantine measures throughout Ukraine in connection with the spread of coronavirus (COVID-19) has dramatically affected all spheres of human life and social processes that have traditionally taken place. Thus, one of the items of these measures was the ban on traditional (full-time) forms of education, the closure of all educational institutions and the introduction of a quarantine regime, the ban on mass gatherings. The speed of implementation of quarantine measures and the lack of any preparation for this case came as a shock to pupils and students, as well as for educational institutions together with teachers. This phenomenon will have long-term consequences for the entire educational sphere, not only in our country, but also around the world. Therefore, the purpose of our article is to review the use of educational platforms in the study of a foreign language during quarantine activities within distance learning, its advantages and disadvantages.

Background literature review. Domestic and foreign pedagogical works, which reveal the theory and practice of distance learning of foreign languages, cover the following topics of research: scientific support of distance learning, problems and areas of research in this field (Bykov, 2005; Jacob \& Ensign, 2020); organizational and pedagogical bases of distance education abroad and in Ukraine, approaches to their implementation (Ghurevych \& 
Kademija, 2007; Ghajsha, 2007); psychological and pedagogical aspects and technologies of creating a distance course (Kukharenko \& Bondarenko, 2020); prospects of distance learning in higher educational institutions (universities) of Ukraine and abroad (Stefanenko, 2003); control of knowledge and its evaluation (Ivanov, 2002); distance learning of foreign languages (Zhulkevska, 2002; Martyushev et. al., 2021; Köprülü et al., 2019; Nugroho et al., 2021; Lestiyanawati \& Widyantoro, 2020); development and use of multimedia and computers in teaching various subjects, such as foreign languages (Mukan, 2010; Romanovska et. al., 2020).

Distance learning is "a purposeful, specially organized process of students' interaction with each other and the teacher by means of information and communication technologies (ICT)" (Andreev \& Soldatkyn, 2020).

Distance learning (DL) in teaching English is an educational process using a set of telecommunication technologies aimed at providing students with the opportunity to master the bulk of the information they need without direct contact between students and teachers during the learning process (which can take place both in synchronous and asynchronous form), and which can be both an independent form of training and an addition to another, more traditional form of training (full-time, part-time or external studies), giving a person the opportunity to study a course of training, retraining or advanced training in the discipline "Foreign Language" he requires, without changing the usual way of life (Artyukhov, 2021).

Distance learning in teaching English is the interaction between the teacher and students at a distance, which reflects all the components inherent in the educational process (goals, content, methods, organizational forms, teaching aids). DL is implemented using specific means of Internet technology or other means of interactivity (Polat, 2006; Mukhtar et al., 2020).

Distance learning in teaching English is an independent form of education; information technologies are the major means in it (Martyushev et. al., 2021).

Distance learning in teaching English is a new form of training at a distance. The popularity of distance education has grown dramatically in recent years (Imanova, 2021). This form of learning is the most flexible and accessible for many people who want to gain knowledge, learn to work independently and plan their time. In distance learning of English, many didactic tasks are solved with the help of new technological capabilities that complement traditional methods of teaching foreign languages. However, for the successful implementation of e-learning of foreign languages in practice, it is necessary to clarify its features and a more thorough study of the main advantages and disadvantages.

The article aims to analyze the features of distance learning in teaching foreign languages in the higher education system and determine the advantages and disadvantages.

Objectives: to determine the effectiveness of the process of distance learning of foreign languages; to outline measures and directions for the improvement and dissemination of distance education; to identify the negative and positive aspects in the process of introducing distance learning of foreign languages in the educational process; to describe the prospects and approaches to solving problems of distance education of foreign languages in higher education.

Materials and Methods. This scientific study is based on the usage of theoretical and empirical methods (systematic method - to identify and evaluate positive and negative effects on the foreign languages learning process in distance learning format; the historical method to study the development of distance learning in teaching English). Statistical data processing was carried out using Google services in conducting surveys used for analyzing the data.

The survey was conducted by interviewing students of Khmelnytsky National University who study English as a foreign language. At the preparatory stage, the aim of the survey was defined - to identify how students assess the quality of the offered educational 
services for distance learning of the foreign language (English) and the degree of pleasure with learning in this format. A questionary was developed. The classification of its questions was based on such criteria as: contents, configuration and function. Based on the study logics, the number of questions was optimum and the answers to them gave a complete information [21-27]. The survey was conducted in May-June 2021; the respondents were 120 students (studying English) of KhNU Bachelor's programs aged 17-19 years.

Main results of the study. Based on the survey results, we can make a conclusion that students react positively to the introduction and implementation of distance language learning. $63 \%$ of respondents consider it to be an auxiliary and temporary training; students highlight the benefits of the distance language learning, primarily the flexibility of the learning process $-69 \%$; emphasize the skills importance in the use of distance learning technologies obtained in the process of e-learning for further professional activities $-81 \%$. During the discussion of the study results, a number of disadvantages were highlighted: the absence of live social communication, the lack of eye-to-eye dialog. $45 \%$ of students consider good technical equipment to be promising for studying English.

The received responses were analyzed and processed via Google services in conducting surveys; they served as the basis for identifying advantages and disadvantages in the development of distance learning of foreign languages.

Among the significant advantages of distance learning of foreign languages we can define the following:

1. Ability to learn at any time. A student who studies remotely can decide for himself when and how much time during the semester to spend on studying the material. He builds an individual training schedule for himself (Bakhov et al., 2021; Fox, 2020).

2. Opportunity to study anywhere. Students can study without leaving home or office, being anywhere in the world. All you need to start learning is a computer with Internet access. The absence of the need to attend school every day is a definite plus for people with disabilities, for people living in hard-to-reach areas, and parents with small children (Fox, 2020; Nashorna, 2021).

3. In-service training. It is not necessary for studying to take a vacation at the main place of work and go on a business trip. You can also study remotely several courses or in several educational institutions at the same time (Demchenko, 2021).

4. Opportunity to learn at your own pace. It is not necessary to study at the same pace as other students. The student can always return to the study of more complex issues, watch video lectures several times, reread correspondence with the teacher. The main thing is to successfully pass the intermediate and final certifications (Rabin, 2018).

5. Availability of educational materials. Access to all necessary literature is opened to the student after registration in the distance learning system, or he receives study materials by e-mail. The problem of lack or absence of textbooks or manuals disappears (Nashorna, 2021; (Rabin, 2018).

6. Mobility. Communication with teachers, tutors is carried out in different ways: both on-line and off-line. Consulting a teacher by e-mail is sometimes more effective and quicker than making a personal meeting in full-time or part-time study (Myronov, 2021; Fox, 2020).

7. Learning in a calm environment. Intermediate certification is passed in the form of on-line tests. Therefore, students have less cause for concern. The possibility of subjective assessment is excluded: the system that checks the correctness of the answers to the test questions will not be affected by the student's success in other subjects, his social status and other factors.

8. Individual approach. In traditional teaching, it is difficult for a teacher to pay the necessary amount of attention to all students in the group, to adjust to the pace of work of each student. The use of remote technologies is suitable for the organization of an individual 
approach. In addition to the fact that the student chooses the pace of study, he can quickly get answers to questions from the teacher (Fox, 2020).

9. Distance education is cheaper. If you compare the cost of part-time learning and distance learning, then distance learning is likely to be cheaper. The student does not have to pay for travel, accommodation, and in the case of foreign universities he does not need to spend on a visa and passport (Berg \& Simonson, 2016).

10. Convenience for the teacher. Teachers, tutors who teach remotely can pay attention to more students and work, even on a business trip or at a conference abroad (Fox, 2020).

Today, not only the teams of the most progressive universities in the country, but also the students themselves, believed in the prospects, vitality of distance learning of foreign languages and its adequacy (in relation to traditional forms).

Ukrainian distance learning of foreign languages is close to our consumer and is democratic. Organically combining mixed technologies of open education (case technologies, TV technologies, network technologies), Ukrainian distance learning of foreign languages becomes the most accessible to the general public, making it possible to obtain education.

The modern information society makes demands on the system of teaching and learning of foreign languages. The main ones can be formulated as follows: 1) the ability to independently find, accumulate and rethink scientific knowledge; 2) the ability of students to navigate independently in the modern information society (Ghryshchenko, 2020).

The quality of implementation of distance learning of foreign languages can be assessed using such indicators as: 1) effectiveness (degree of knowledge acquisition, ability to apply the accumulated knowledge in practice, success, individual learning process, flexible consultations); 2) accessibility to all segments of the population (students, businessmen, the disabled, servicemen and prisoners also have the opportunity to study remotely); 3) resource intensity (no need to attend lectures and seminars, financial costs, material resources, classrooms, teachers, etc.); 4) efficiency (time for mastering knowledge, informing students, etc.); 5) democratic connection "teacher - student"; 6) complex software; 7) leading educational technologies.

Distance learning of foreign languages is developing very fast and is a promising form of higher education for Ukraine. In the West, this form has appeared for a long time and is very popular among students because of its economic performance and educational efficiency. Distance learning of foreign languages is also called "lifelong learning" because most learners are adults. Many of them already have higher education, but due to the need to improve skills or expand the scope of activities, many have a need to quickly and efficiently acquire new knowledge and skills. It is then that distance learning can become the optimal form.

Open education provides a wide field for research that promotes the development of creative initiatives of developers and teachers, moving from the object of study to the object of forecasting, design and engineering (Ovcharuk, 2004).

At the same time, there are several negative aspects that can be encountered in the process of introducing distance learning of foreign languages in the educational process.

1. The coordinating function of the Ministry of Education is too weak (inconsistency in regulatory and legal support, standardization, economic and financial issues, assessments of the quality of education).

2. Competition among universities for students - as the main source of funding - has led to the autonomy of many universities, the secrecy of development, which is also due to the fact that copyright issues are not addressed.

3. The human factor plays an important role in the process of learning the foreign languages, because the teacher, in direct contact with the student, can transfer and instill a number of skills, and in distance education this human factor completely or partially disappears. The absence of people around significantly reduces the effectiveness of the 
learning process. It is difficult to create a creative atmosphere in groups of students if classes are held in front of computer monitors.

4. Existing methods of teaching foreign languages are poorly combined with new technologies; the methodological and educational materials are not suitable for distance learning.

5. Lack of many teachers' skills in working with information technology. In this regard, there are difficulties with the preparation of educational material in foreign languages, suitable for use in distance education.

6 . The resistance of the teaching staff to the introduction of modern technologies.

7. The cost of training teachers in modern information technology, as well as the financial costs of universities to purchase the necessary technical equipment.

8. The need to standardize the requirements for the provided educational materials required for distance learning of foreign languages (Sokolovsjkyj, 2015).

9. In technical terms - weak communication channels, high cost of the Internet.

10. Creating an information and educational environment, especially in terms of filling the database with electronic textbooks and teaching materials.

11. Increasing the capacity of the telecommunications channel, the development of the corporate network of universities and branches to a level that ensures the organization of the educational process for all types of educational activities and technologies of pedagogical communication.

12. One of the main problems of e-learning is still the authentication of users when testing knowledge. Because the best technological solutions have not yet been proposed, most remote programs still have a stationary examination session. It is impossible to know who is on the other side of the screen. In some cases, this is a problem and requires special measures, additions and skills of tutors. Part of this problem is solved by installing video cameras on the training side and programs.

13. Practically the material is mastered by the distance student independently. This requires sufficient willpower, responsibility and self-control. Most likely, no one will encourage the student to study. Not everyone is able to maintain the right pace of learning without outside control (Fox, 2020).

14. Lack of practical skills. It is quite problematic to organize distance learning in the areas of training and specialties, which provide a large number of practical classes. Even state-of-the-art computer simulators will not replace future "living" practice specialists (Ghabrusjev, 2011).

To improve and disseminate high-distance technologies for foreign language learning, it is necessary to implement the following priority measures and areas:

1. development and implementation of the All-Ukrainian program of distance continuing education;

2. eradication of contradictions in the legislation on education in Ukraine, bringing it in line with the objective needs and trends of distance learning of foreign languages;

3. development of scientific bases that ensure the innovation of both distance forms and levels of education, programs and curricula in foreign languages;

4. scientific substantiation of the market of educational literature, computer and multimedia databases, exclusion of the possibility of its monopolization;

5. creation of variable methods of distance learning of foreign languages for people with different levels of abilities, age and needs;

6. ensuring the transition to interactive methods and practical orientation of distance learning of foreign languages;

7. creation of a system of support for projects, innovations in distance education technology, its correspondence and other forms; 
To solve the problem of quality of educational services received by distance learning students, foreign language teachers must develop and implement information technologies that promote the development of distance education. Distance learning at the university gives students the opportunity for round-the-clock access to educational materials, constant support and consultations of teachers and methodologists, on-line video lectures, virtual simulators and other technological solutions to ensure an effective learning process.

Regardless of the characteristics of the information-subject environment, the linguodidactic tasks and features of cognitive activity of students will be in the foreground, because they are determined by the specific goals of education. Therefore, distance language learning based on Internet resources is a fundamental means of implementing these tasks (Fox, 2021). Modern means of communication with partners, access to information resources of the Internet, provide mastery not only of computer technology but also of foreign languages. It is no coincidence that UNESCO has declared our century the century of polyglots. The primary value in the age of informatization is information. The specificity of the discipline "Foreign language" is that the fundamental component of the content of foreign language learning is not a scientific basis, but methods of work - learning the different types of speech activities: speaking, listening, reading and writing. Therefore, to teach students different types of professional activities, it is necessary to provide each student with the opportunity to practice the type of professional activity that he defines at the moment. Speech training is possible only in a living society. Thus, a partner is needed. In the process of computer telecommunications, the student can have a live conversation (oral or written) with a teacher or a group friend (Malyuga \& Ponomarenko, 2012).

Based on the specifics of the discipline, knowing the linguistic and didactic features and functions of distance language learning courses, we can identify the types of goals that can be achieved in the application of these tasks. This makes the educational process more accessible and organized compared to classical learning. For example, in a city where people (who want to learn a foreign language) live, there are no special courses. To start distance learning, it is possible to find an interesting course on the Internet and register on the site. The test task can be created on a special learning platform, where you can maintain a chat with the teacher, receive grades and comments on the completed tasks. As there are no formal restrictions on the principles of learning, it becomes easier for both students and teachers to organize the educational process. A person can study in a country on another continent at a convenient time, without the need for visas, tickets and accommodation. As a rule, distance learning is cheaper than classical learning, primarily by reducing the cost of moving, as well as living in another city.

Thus, distance learning in English provides an opportunity to work with highly qualified teachers around the world and, thus, to involve faculty in the work without taking into account the place of residence and main work of teachers. This type of training provides a real opportunity to work with professional teachers who work not only in Ukrainian educational institutions, but also in foreign ones.

Summing up, despite all the negative aspects of distance education, we want to express hope for the introduction of existing information technologies in the educational process of universities and the development of new technologies more advanced in form and adapted to teaching foreign languages and Ukrainian conditions.

Conclusions. The need to shape the human being of the next millennium is a serious challenge to the world education system. As clearly and adequately we can identify and implement new learning technology and its distance forms that improve the quality and increase the mass of education, so productively the national school of education will fulfill this historic order to create a new civil society in our country. 
Distance learning of foreign languages in world practice is one of the established forms of learning. It is in demand by society, it is popular. Distance learning of foreign languages is the most democratic form of education that allows educating the general public. Methods of distance learning of foreign languages are used in universities, school education, the system of in-service training of teachers, the system of management training.

Distance learning in a reputable educational institution has the same academic and professional value as its traditional counterpart, and this form of training can be especially useful for people who want to strengthen their careers, get a promotion or just satisfy their thirst for knowledge, and understanding the details of how distance learning is carried out, can help decide whether such a learning option is suitable for educational and career paths.

The perspective and improvement of the system of distance learning of foreign languages in Ukraine is the introduction of computer and audio-visual equipment in the educational process. Currently, the problem of distance education is developed by almost all universities in Ukraine.

In the future, e-learning will make learning not a boring and carefully planned commitment, but an exciting cognitive process in the formation of which the student participates himself. Learning everywhere, always and all your life with pleasure is about the slogan of the idea of distance education.

\section{REFERENCES}

Bykov, V.Ju. (2005). Distance education: relevance, features and principles of construction, ways of development and scope. Information support of the educational process: innovative tools and technologies: Collective monograph. K.: Atika, 77-92 (in Ukrainian).

Jacob, J.U. \& Ensign M. (2020). Transactional Radio Instruction: Improving Educational Outcomes for Children in Conflict Zones, Palgrave Macmillan, Cham. DOI: https://doi.org/10.1007/978-3-030-32369-1

Ghurevych, R. \& Kademija, M. (2007) Online learning through e-learning courses. Vocational education, 4, 24-27 (in Ukrainian).

Ghajsha, O. O. (2007). Modern distance education: technologies, tools and support [Text]. Problems of education: scientific methodological book. Ministry of Education and Science of Ukraine, Institute of Innovation technologies and content of education, 50, 25-30 (in Ukrainian).

Kukharenko, V.M. \& Bondarenko, V.V. (2020). Emergency distance learning in Ukraine: Monograph. Kharkiv:. Vyd-vo KP «Misjka drukarnja» (in Ukrainian).

Stefanenko, P.V. (2002). Theoretical and methodical bases of distance learning in higher school: dissertation abstract for science degree of Doctor of Pedagogical Science: speciality 13.00.04. K.: Institute of Pedagogy and Psychology of Vocational Education of Academy of Educational Sciences of Ukraine (in Ukrainian).

Ivanov, S.V. (2002). The system of distance education in Ukraine: modern directions of development. Humanities, 2, 12-19 (in Ukrainian).

Zhulkevska, V. (2002). Theoretical and methodological bases of distance learning. Pedagogy, psychology of vocational education, 1, 52-59 (in Ukrainian).

Martyushev, N.;Shutaleva, A.; Malushko, E.; Nikonova, Z.; Savchenko, I. Online Communication Tools in Teaching Foreign Languages for Education Sustainability. Sustainability 2021, 13, 11127. https://doi.org/10.3390/su131911127

Köprülü, F., \& Öznacar, B. (2019). Analysis of University Students' Attitudes Towards Distance Learning in Foreign Language Education Based on Various Variables. BRAIN. Broad Research in Artificial Intelligence and Neuroscience, 10(1), 123-128. https://lumenpublishing.com/journals/index.php/brain/article/view/2136 
Nugroho, A., Ilmiani, D., \& Rekha, A. (2021). EFL Teachers' Challenges and Insights of Online Teaching amidst Global Pandemic. Metathesis: Journal of English Language, Literature, and Teaching, 4(3). https://doi.org/10.31002/metathesis.v4i3.3195

Lestiyanawati, R., \& Widyantoro, A. (2020). Strategies and Problems Faced by Indonesian Teachers in Conducting E- Learning System During COVID-19 Outbreak. Journal of Culture, Literature, Linguistic and English Teaching, 2(1), 71-82.

Mukan, N.V. (2010). Continuing pedagogical education of secondary school teachers. Professional formation and development on the materials of Great Britain, Canada, USA. Monograph; T.G. Shevchenko Kyiv National University. Lviv: Lviv Polytechnic University (in Ukrainian).

Romanovska, L., Kravchyna, T., Korolova, N., Oliynyk, K. ., \& Nagachevska, O.(2020). Personal Reflection Development as Means of Forming Culture of Scientific Text Perception by Humanitarians. BRAIN. Broad Research in Artificial Intelligence and Neuroscience, 11(4), 118-131. https://doi.org/10.18662/brain/11.4/144

Andreev, A.A. \& Soldatkyn, V.I. (2013). Distance learning and distance educational technologies. Cloud of science, 1. URL: https://cyberleninka.ru/article/n/distantsionnoeobuchenie-i-distantsionnye-obrazovatelnye-tehnologii (access date: 15.06.2020) (in Russian).

Artyukhov, A.A. (2021). Some aspects of theory and practice of the organization of "distance learning" when studying geography at the basic school. International Research Journal, 5, 51. ISSN 2303-9868. Doi: 10.23670 / IRJ.2021.107.5.111. (in Russian) Russian)

Polat, E. S. (2006). Pedagogical technologies of distance learning. M.: Akademija (in

Mukhtar, Khadijah; Javed, Kainat; Arooj, Mahwish; Sethi, Ahsan (May 2020). "Advantages, Limitations and Recommendations for online learning during COVID-19 pandemic era". Pakistan Journal of Medical Sciences. 36 (COVID19-S4): S27S31. Doi:10.12669/pjms.36.COVID19-S4.2785. ISSN 1682

024X. PMC 7306967. PMID 32582310.

Imanova, S. (2021). Promoting Azerbaijani Students' Intercultural Competence through Distance Education of Foreign Languages. Arab World English Journal, 12 (3) 232- 241. DOI: https://dx.doi.org/10.24093/awej/vol12no3.16

Bakhov, I., Opolska, N., Bogus, M., Anishchenko, V., Biryukova, Y. (2021). Emergency Distance Education in the Conditions of COVID-19 Pandemic: Experience of Ukrainian Universities. Education $\quad$ Sciences, 11(7):364. https://doi.org/10.3390/educsci11070364 Retrieved from https://www.mdpi.com/22277102/11/7/364/htm

Fox, Alice (2020). What Are The Advantages And Disadvantages That Distance Education Can Offer You? Elearning Trends.

https://elearningindustry.com/advantages-and-disadvantages-distance-education-offer

Nashorna, Alyona (2021). Distance education: advantages and disadvantages. https://blog.stu.cn.ua/2021/10/29/distance-education-advantages-and-disadvantages/

Demchenko, M. (2021). Distance learning benefits.

https://www.studocu.com/en-us/document/canada-college/study-guides/distance-learningbenefits/11428737

Rabin, Ruhani (2018). Tops 5 pros and cons of online education. https://www.ruhanirabin.com/pros-cons-online-education/

Myronov, Yu.B. (2021). Advantages and disadvantages of distance learning. http://kerivnyk.info/perevahy-ta-nedoliky-dystantsijnoho-navchannya (in Ukrainian).

Berg, Gary \& Simonson, Michael. (2006), Distance learning. Encyclopedia Britannica. https://www.britannica.com/topic/distance-learning. 
Ghryshchenko, O.S. (2020) Problems of development of distance form of education in Ukraine. In O.M. Nifatova (Ed.). Innovation in education, science and business: challenges and opportunities: materials of the I All-Ukrainian conference of applicants for higher education and young scientists (November 17, 2020, Kyiv) (pp.74-78). Kyiv: KNUTD (in Ukrainian).

Ovcharuk, O.V. (2004). Distance education in European countries and USA in the context of development of innovative technologies. Computer at school and family, 7, 37-40 (in Ukrainian).

29. Sokolovsjkyj, Ya.I. (2015). Application of modern information and communication technologies for the organization of distance learning. Scientific Bulletin of National Forestry University of Ukraine, 25 (6), 243-248 (in Ukrainian).

Ghabrusjev, V.Yu. (2011). Distance learning is simple. K.: Shk. World, 2011 (Library "School World") (in Ukrainian).

Malyuga, E. \& Ponomarenko, V. (2012). Distance teaching English for specific purposes. 5th International Conference of Education, Research and Innovation. https://www.researchgate.net/publication/298971338_DISTANCE_TEACHING_ENGLISH_ FOR_SPECIFIC_PURPOSES

Text of the article was accepted by Editorial Team 16.09.2021 p.

\title{
ДИСТАНЦЙНЕ НАВЧАННЯ І ВИКЛАДАННЯ АНГЛІЙСЬКОЇ МОВИ: ПЕРЕВАГИ ТА НЕДОЛІКИ
}

\author{
Кравчина Тетяна Володимирівна \\ Кандидат психологічних наук, доцент кафедри іноземних мов, \\ Хмельницький національний університет, Хмельницький, Україна \\ tkravchyna@gmail.com \\ ORCID: 0000-0001-8407-6667
}

\begin{abstract}
Анотація. Електронне навчання іноземних мов набуває великого значення через зростання інтересу до інтернету. Воно стає популярним методом завдяки своїй доступності, простоті та перспективності, які сприяють покращенню спектра та якості дистанційного навчання при викладанні англійської мови у вищих навчальних закладах в умовах пандемії. Механізм навчання - ключовий процес людського життя, який визначає розвиток особистості. Швидкі темпи розвитку інформаційних технологій призводять до витіснення традиційного навчання у вищих навчальних закладах за допомогою більш сучасних методів, включаючи дистанційне навчання при викладанні англійської мови. Ця стаття намагається відобразити сучасні тенденції у вивченні іноземних мов за допомогою дистанційних технологій. В даний час нові технології та інтернет дозволяють людині отримати необхідні знання, не виходячи 3 дому, користуючись персональним комп'ютером. У цій статті розглядаються переваги та недоліки дистанційного навчання у викладанні іноземної мови порівняно з денною та заочною формами навчання. Аналіз опитування підтверджує, що якість та структура навчальних курсів, як правило, набагато краща в дистанційному навчанні, ніж в традиційних формах навчання. Дистанційне навчання охоплює всі практичні методи навчання та пропонує велику кількість завдань, призначених для самостійного навчання, 3 ймовірністю отримання повсякденних консультацій. Воно використовує найновіші досягнення інтерактивних та інформаційних технологій та надає рівні можливості навчання студентам незалежно від стану здоров'я, місця проживання, фінансової безпеки та елітарності. Крім того, у статті наведено та пояснено недоліки цієі форми навчання над іншими формами та причини, чому дистанційна освіта може бути неефективною (відсутність бесіди віч-на-віч, одностороннє пояснення та відсутність конструктивних навичок). Студент також повинен мати певні психологічні риси та технічні засоби, такі як комп'ютер та доступ до інтернету. Висновки, зроблені в результаті порівняння, дозволяють визначити сфери, що потребують особливої уваги, а також вибрати найбільш зручні інструменти для ефективного вивчення іноземних мов та англійської, зокрема.
\end{abstract}

Ключові слова: навчання; дистанційне навчання; англійська мова; переваги і недоліки; сучасні технології 